\title{
Demonstration of Intermediate Cells during Human Prostate Epithelial Differentiation In Situ and In Vitro Using Triple-Staining Confocal Scanning Microscopy
}

\author{
Geert van Leenders, Henry Dijkman, Christina Hulsbergen-van de Kaa, Dirk Ruiter, \\ and Jack Schalken
}

Departments of Pathology (GvL, HD, CHvdK, DR) and Urology (GvL, JS), University of Nijmegen, Nijmegen, The Netherlands

\begin{abstract}
SUMMARY: In human prostate epithelium, morphologically basal and luminal cells can be discriminated. The basal cell layer that putatively contains progenitor cells of the secretory epithelium is characterized by the expression of keratins (K) 5 and 14. Luminal cells represent the secretory compartment of the epithelium and express $\mathrm{K} 8$ and 18. We developed a technique for the simultaneous analysis of $\mathrm{K} 5,14$, and 18 to identify intermediate cell stages in the prostate epithelium and to study the dynamic aspects of its differentiation in vitro. Nonmalignant prostate tissue and primary epithelial cultures were immunohistochemically characterized using triple staining with antibodies for $\mathrm{K} 5, \mathrm{~K} 14$, and $\mathrm{K} 18$. Antibodies for $\mathrm{K} 18$ and $\mathrm{K} 5$ were conjugated directly with fluorochromes Alexa 488 and 546. K14 was visualized indirectly with streptavidin-Cy5. Keratin expression was analyzed by confocal scanning microscopy. The occurrence of exocrine and neuroendocrine differentiation in culture was determined via antibodies to prostate-specific antigen (PSA), chromogranin A, and serotonin. We found that basal cells expressed either $\mathrm{K} 5^{++} / 14^{++} / 18^{+}$or $\mathrm{K} 5^{++} / 18^{+}$. The majority of luminal cells expressed $\mathrm{K} 18^{++}$, but colocalization of $\mathrm{K} 5^{+} / 18^{++}$were recognized. Epithelial monolayer cultures predominantly revealed the basal cell phenotype $\mathrm{K} 5^{++} / 14^{++} / 18^{+}$, whereas intermediate subpopulations expressing $\mathrm{K}^{+} / 14^{+} / 18^{++}$and $\mathrm{K}^{+} / 18^{++}$were also identified. On confluence, differentiation was induced as multicellular gland-like buds, and extensions became evident on top of the monolayer. These structures were composed of $\mathrm{K} 18^{++}-$and $\mathrm{K}^{+} / 18^{+}$-positive cell clusters surrounded by phenotypically basal cells. Few multicellular structures and cells in the monolayer showed exocrine differentiation ( $\mathrm{PSA}^{+}$), but expression of chromogranin $\mathrm{A}$ and serotonin was absent. We conclude that simultaneous evaluation of keratin expression is useful for analyzing epithelial differentiation in the prostate. During this process, putative stem cells phenotypically resembling $\mathrm{K}^{++} / 14^{++} / 18^{+}$differentiate toward luminal cells $\left(\mathrm{K} 18^{++}\right.$) via intermediate cell stages, as identified by up-regulation of K18 and down-regulation of K5 and 14. (Lab Invest 2000, 80:1251-1258).
\end{abstract}

$W$ ithin the secretory epithelium of the human prostate, morphologically basal and luminal cells can be discriminated. The basal cell layer is believed to contain the stem cell population of the prostate epithelium (English et al, 1987; Kyprianou and Isaacs, 1988; Robinson et al, 1998; Verhagen et al, 1988). This stem cell population has a long life span and a large proliferative capacity. Isaacs and Coffey described a model in which stem cells on self-renewal give rise to a transiently proliferating (TP)/amplifying cell population that has a shorter life span and limited cyclic activity (Isaacs and Coffey, 1989). This cell population is situated in the basal as well as the luminal cell layer, and finally differentiates into exocrine or neuroendocrine cells (Xue et al, 1997, 1998). Exocrine differentiation occurs in the majority of the luminal cells and is identified by expression of prostate-specific antigen (PSA). Neuroendocrine cells are dispersed in the prostate

Received March 20, 2000.

Address reprint requests to: Dr. Geert van Leenders, Department of Pathology, University Hospital Nijmegen, P.O. Box 9101, 6500 HB Nijmegen, The Netherlands. Fax: 3124 3540520; E-mail: G.vanleenders@ pathol.azn.nl epithelium and secrete neuropeptides like chromogranin A and serotonin. Recently, the TP/amplifying cells have gained attention because they indicate the existence of a hierarchic relationship in the prostate epithelium and putatively play a role in neoplastic diseases.

Expression of keratins $(\mathrm{K})$ has gained validity as a marker for cell lineage differentiation. Keratins belong to the group of intermediate filament proteins that form the cell skeleton by heterodimeric interaction (Moll et al, 1982). Epithelial cells express subgroups of keratins, enabling discrimination between basal and luminal localization. As in all simple epithelia, luminal cells in the human prostate express K8 and 18 (Okada et al, 1992; Sherwood et al, 1990, 1991). Basal cells are originally identified by their expression of $\mathrm{K} 5$ and 14 , but $\mathrm{K} 8$ and 18 are present in at least a subset of them (Nagle et al, 1991; Yang et al, 1997). A few studies also report colocalization of "basal" and "luminal" keratins in the luminal cell layer, interpreted as an intermediate phenotype in the prostate (Verhagen et al, 1988, 1992). These intermediate cells are candidates for the TP/amplifying cells in the prostate. The keratin expression of neuroendocrine cells is complex and not yet fully elucidated, but it resembles that of 
intermediate cells (Bonkhoff et al, 1994; Xue et al, 1997).

The cellular origin of cancer development requires an understanding of epithelial differentiation. Prostate carcinoma is clinically described as an androgendependent disease and therapeutic withdrawal of androgens usually results in tumor regression. However, the disease finally progresses to an androgenindependent status in which it no longer responds to androgen blockade and no therapeutic options are available. To understand the cell biology aspects of this, evaluation of keratin expression is useful because it identifies the epithelial composition of prostate cancer. In general, prostate carcinoma has a luminal cell phenotype $\left(\mathrm{PSA}^{+}, \mathrm{K}^{+} 8^{+}\right)$; it was therefore postulated that malignant transformation of this cell type results in the origin of prostate carcinoma (Nagle et al, 1987; Okada et al, 1992; Sherwood et al, 1990; Yang et al, 1997). Several studies, however, also describe the presence of basal cell characteristics in prostate carcinoma (Googe et al, 1997; Verhagen et al, 1992; Yang et al, 1999). Interestingly, an increase of basal markers is associated with androgen-independent tumor progression (Gil-Diez de Medina et al, 1998; McDonnell et al, 1992). This led to the hypothesis that an alternative cell type is involved in carcinogenesis of the prostate, that is the amplifying cell (Isaacs and Coffey, 1989; Verhagen et al, 1992). Investigation of the stem cell lineage in secretory prostate epithelium is therefore crucial to understanding the role of TP/amplifying cells in carcinogenesis and cancer progression in the prostate.

Identification of the cell biology characteristics of intermediate, TP/amplifying cells has been hampered by lack of a technique that can adequately visualize "basal" and "luminal" markers in the same cell. In this study, we describe a method for simultaneous analysis of $\mathrm{K} 5,14$, and 18 . We directly demonstrate the existence of intermediate cell stages in normal human prostate epithelium and provide a cell culture model for the study of its differentiation.

\section{Results \\ Analysis of Keratin Expression Using Confocal Laser Scanning Microscopy}

Analysis of keratin expression using immunofluorescence and confocal laser scanning microscopy (CLSM) enables the simultaneous detection of K5, 14, and 18 in a single cell. Each labeled keratin produces a different fluorescent signal that is depicted as a specific color. Expression of $\mathrm{K} 5$ is represented by red, K14 by blue, and K18 by green. It should be emphasized that $\mathrm{K} 14$ labeled with $\mathrm{Cy} 5$ originally generates a red fluorescent signal ( $670 \mathrm{~nm})$, which is depicted by blue for image analysis; this allows distinction between K14 and the red signal of Alexa 546-labeled K5 $(573 \mathrm{~nm})$. Coexpression of keratins is identified by hybrid colors. Colocalization of red (K5) and green (K18) is depicted as yellow (K5/18), and a pink/purple color (K5/14) represents expression of red (K5) and blue (K14). Simultaneous perception of red (K5), green (K18), and blue $(\mathrm{K} 14)$ produces a white $(\mathrm{K} 5 / 14 / 18)$ hybrid color.

\section{Keratin Expression In Situ}

At least four different cell types were distinguished in the human secretory prostate epithelium by their pattern of keratin expression. The majority of the luminal cells strongly expressed $\mathrm{K} 18\left(\mathrm{~K}_{18^{++}}\right)$, but single cells and cell clusters showed co-expression of $\mathrm{K} 5$ and 18 $\left(\mathrm{K}^{+} / 18^{++}\right)$. $\mathrm{K} 18$ expression was weak in the basal cell layer. All basal cells strongly expressed $\mathrm{K} 5\left(\mathrm{~K}^{++} /\right.$ $\left.18^{+}\right)$, and a subpopulation was also positive for $\mathrm{K} 14$ $\left(\mathrm{K}^{++} / 14^{++} / 18^{+}\right)$(Fig. 1).
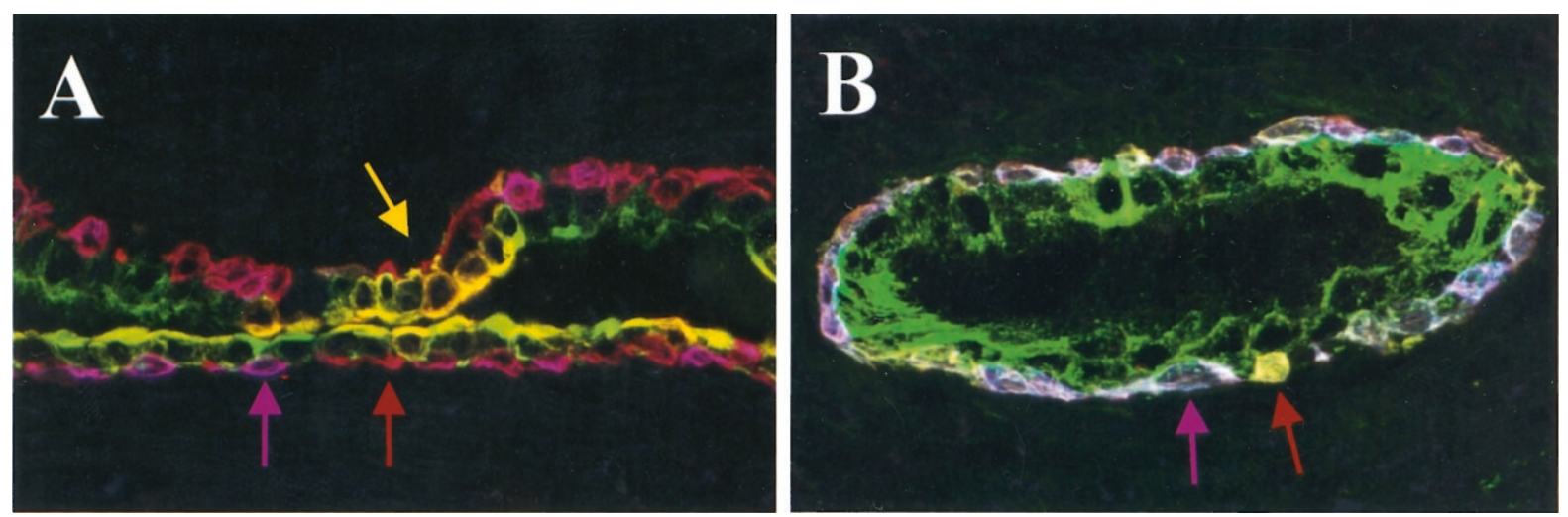

\section{Figure 1.}

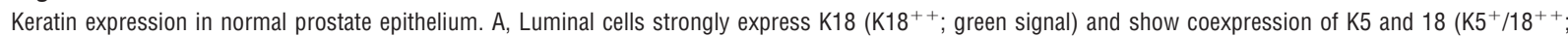
hybrid yellow signal). Two cell populations are discriminated in the basal cell layer. All basal cells show strong expression of K5 and are weakly positive for K18, only detectable at higher sensitivity levels of the scanning microscope $\left(\mathrm{K}^{++} / 18^{++}\right.$; red signal). Colocalization of $\mathrm{K} 5,14$, and $18\left(\mathrm{~K} 5^{++} / 14^{++} / 18^{+}\right.$; hybrid purple signal) is encountered in a subpopulation of basal cells. B, At a higher detection level, K18 is demonstrated in all basal cells. Colocalization of K5 and 18 in basal cells is shown by a hybrid yellow signal $\left(\mathrm{K} 5^{++} / 18^{+}\right)$and coexpression of $\mathrm{K} 5,14$, and 18 by a white signal $\left(\mathrm{K} 5^{++} / 14^{++} / 18^{+}\right)$. $\mathrm{K} 18$ and $\mathrm{K} 5$ are directly labeled with Alexa 488 (green) and 546 (red), respectively. K14 is visualized with Cy5 (blue). Colored arrows indicate hybrid signals: red arrow K5 ${ }^{++} / 18^{+}$, purple arrow $\mathrm{K} 5^{++} / 14^{++} / 18^{+}$, and yellow arrow $\mathrm{K}^{+} / 18^{++}$. Confocal laser scanning microscopy (CLSM); original magnification, $\times 630$. 


\section{Cell Culture Morphology}

After adherence, epithelial cells proliferated and formed cell clusters that grew in a monolayer. The morphology of these cells varied from small angular cells with scant cytoplasm to large round cells with abundant cytoplasm. A few cells had multiple cytoplasmic neurite-like extensions and were situated either within or on top of the monolayer. After confluence of cell clusters, multicellular gland-like buds and extensions were formed on top of the monolayer. In the beginning, one to three rounded cells were situated above the plane of the monolayer. Within 1 day, buds were formed with a maximal height of $30 \mu \mathrm{m}$ that often made connection by multicellular extensions (Fig. 2). No lumina could be identified within the gland-like structures. The capacity to form these structures decreased in cultures of higher passage number. The maximal life span of epithelial cultures was eight passages.

\section{Keratin Expression In Vitro}

Based on their keratin expression, three epithelial cell types were distinguished growing in the monolayer. Two cell types were strongly positive for $\mathrm{K} 5$ and 14 . Most of these cells weakly co-expressed $\mathrm{K} 18\left(\mathrm{~K}^{++} /\right.$ $14^{++} / 18^{+}$) associated with a basal cell phenotype, and few cells showed intense expression of K18 $\left(\mathrm{K}^{+} / 14^{+} / 18^{++}\right)$. These cells $\left(\mathrm{K} 5^{+} / 14^{+} / 18^{++}\right)$either had an angular shape or showed several cytoplasmic extensions that seemed to contact neighboring cells, suggestive of neuroendocrine differentiation. This particular cell type was growing either within or on top of the monolayer. A third cell type expressed $\mathrm{K} 5$ and 18, but not $\mathrm{K} 14\left(\mathrm{~K}^{+} / 18^{+}\right)$. Subtle variations were observed in the quantity of the respective keratins, indicating up- and down-regulation of these proteins (Fig. 3).

At the beginning of the gland-like budding, small cell groups emerged above the monolayer and were positive for both $\mathrm{K} 5$ and 18, or $\mathrm{K} 18$ alone. The gland-like buds and extensions had a complex cell composition, in which an outer and inner cell compartment were distinguished, as analyzed by CLSM. The outer layer consisted predominantly of flat cells that expressed $\mathrm{K} 5,14$, and $18\left(\mathrm{~K} 5^{++} / 14^{++} / 18^{+}\right)$to the same extent as the cells growing in the monolayer. Cells in the central part of the gland-like structures were usually positive for $\mathrm{K} 18\left(\mathrm{~K}_{18}^{++}\right)$alone, or showed coexpression of $\mathrm{K} 5$ and $18\left(\mathrm{~K} 5^{+} / 18^{+}\right)$(Fig. 4).

The expression of activated caspase-3 was analyzed to exclude the possibility that multicellular buds and extensions were merely aggregations of apoptotic cells that had been released from the monolayer. Single cells found on top of the monolayer and a few cells within the multicellular structures expressed activated caspase-3, indicative of apoptosis. However, most cells within the gland-like structures did not reveal signs of apoptosis.

Secretion of PSA, chromogranin A, and serotonin occurs during differentiation in the prostate. Within the monolayer and gland-like structures, dispersed cells showed exocrine differentiation as identified by PSA expression. There was no expression of chromogranin A or serotonin, particularly in cells with cytoplasmic extensions. This contrasts with the morphology of these cells, which was suggestive of neuroendocrine differentiation.

\section{Discussion}

Keratins are a subclass of cytoskeletal proteins that serve as specific differentiation markers for normal epithelium and as well as for cancer cells (Moll et al, 1982). Simultaneous analysis of K5, 14, and 18 expression demonstrates a gradual shift of these proteins during epithelial differentiation in the prostate and is a useful technique for discriminating epithelial subpopulations. Basal cells within the normal prostate epithelium express either K5/14/18 or K5/18. Although $\mathrm{K} 18$ is generally seen as a luminal cell marker, several reports describe its basal expression on the mRNA and protein level (Nagle et al, 1991; Yang et al, 1997). This inconsistency might be explained by the low expression intensity of K18 in the basal cell layer, as shown in this study. Whereas the majority of luminal cells show expression of $\mathrm{K} 18$ alone, colocalization of $\mathrm{K} 5 / 18$ is regularly encountered. The heterogeneous expression of keratins, as described in this study, was
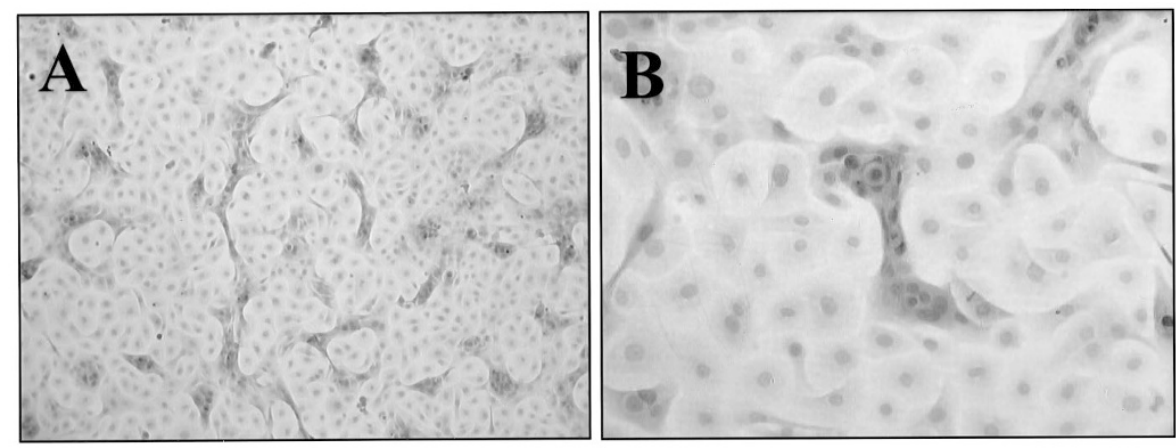

\section{Figure 2.}

Morphology of the prostate epithelial cell culture. Gland-like buds and extensions are formed on top of the monolayer after confluence. Hematoxylin stained; original magnification, $A, \times 40, B, \times 100$. 

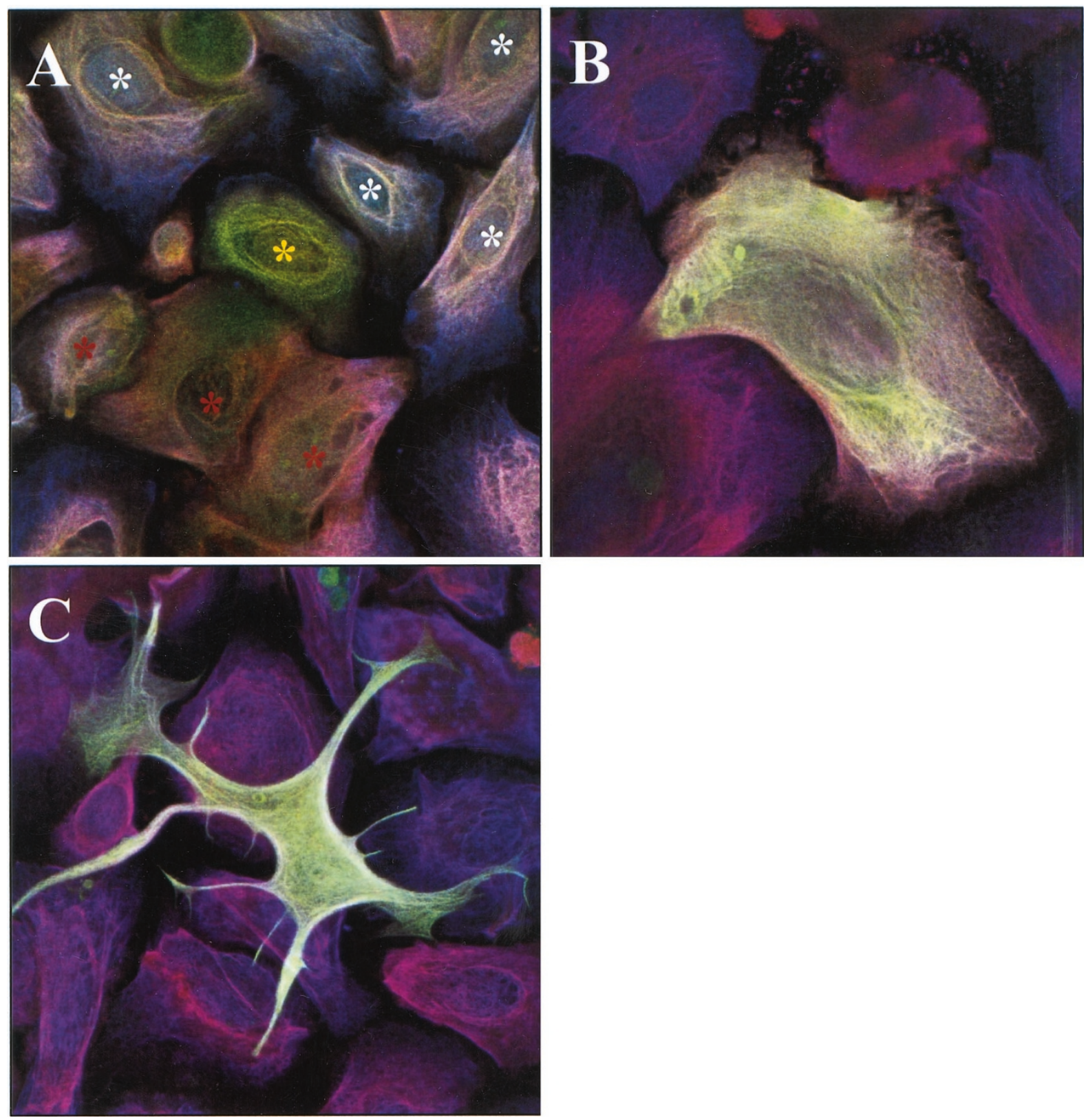

\section{Figure 3.}

Keratin expression in the epithelial cell culture. Three distinct epithelial cell types are found in monolayer culture. A, Most epithelial cells are strongly positive for K5 and 14, but show weak expression of $\mathrm{K} 18\left(\mathrm{~K}^{++} / 14^{++} / 18^{+}\right.$; white asterisk). Expression of $\mathrm{K} 14$ is decreased in a subpopulation of epithelial cells (red asterisk) and sporadically absent $\left(\mathrm{K} 5^{++} / 18^{+}\right.$; yellow asterisk). B and C, Some cells express high levels of $\mathrm{K} 18\left(\mathrm{~K} 5^{+} / 14^{+} / 18^{++}\right)$. These cells either have an angular shape (B) or reveal several cytoplasmic extensions $(C)$. The latter cell type is also encountered on top of the monolayer. Note stronger sensitivity level for the K18-Alexa 488 signal in A. CLSM, original magnification, $\times 630$.

indicated previously in an indirect way (Verhagen et al, 1988, 1992). Direct triple staining advantageously potentiates epithelial characterization in culture and the analysis of additional markers in intermediate cell stages. The keratin profiles described in this study suggest a hierarchic relationship within the human prostate epithelium in which a putative stem cell population $\left(\mathrm{K}^{++} / 14^{++} / 18^{+}\right)$gives rise successively to intermediate cells $\left(\mathrm{K}^{++} / 18^{+}\right.$and $\left.\mathrm{K} 5^{+} / 18^{++}\right)$and terminally differentiated cells $\left(\mathrm{K}_{1} 8^{++}\right)$.

A cell culture model was developed to study the kinetics of epithelial differentiation. Two growth phases can be distinguished in epithelial cell culture. The first expansion phase is characterized by growth of cells in the monolayer that express $\mathrm{K} 5$ and $\mathrm{K} 14$, with minor expression of $\mathrm{K} 18$, indicating a basal cell phenotype. The predominance of basal cells in the primary culture corresponds with the observations of others (Cussenot et al, 1994; Peehl et al, 1994; Robinson et al, 1998). The triple-staining technique enabled the detection of two distinct cell types, with an intermediate keratin expression pattern in the monolayer. The first cell type expressed high levels of $\mathrm{K} 5$, $\mathrm{K} 14$, and $\mathrm{K} 18$. The second cell type expressed $\mathrm{K} 5$ and 

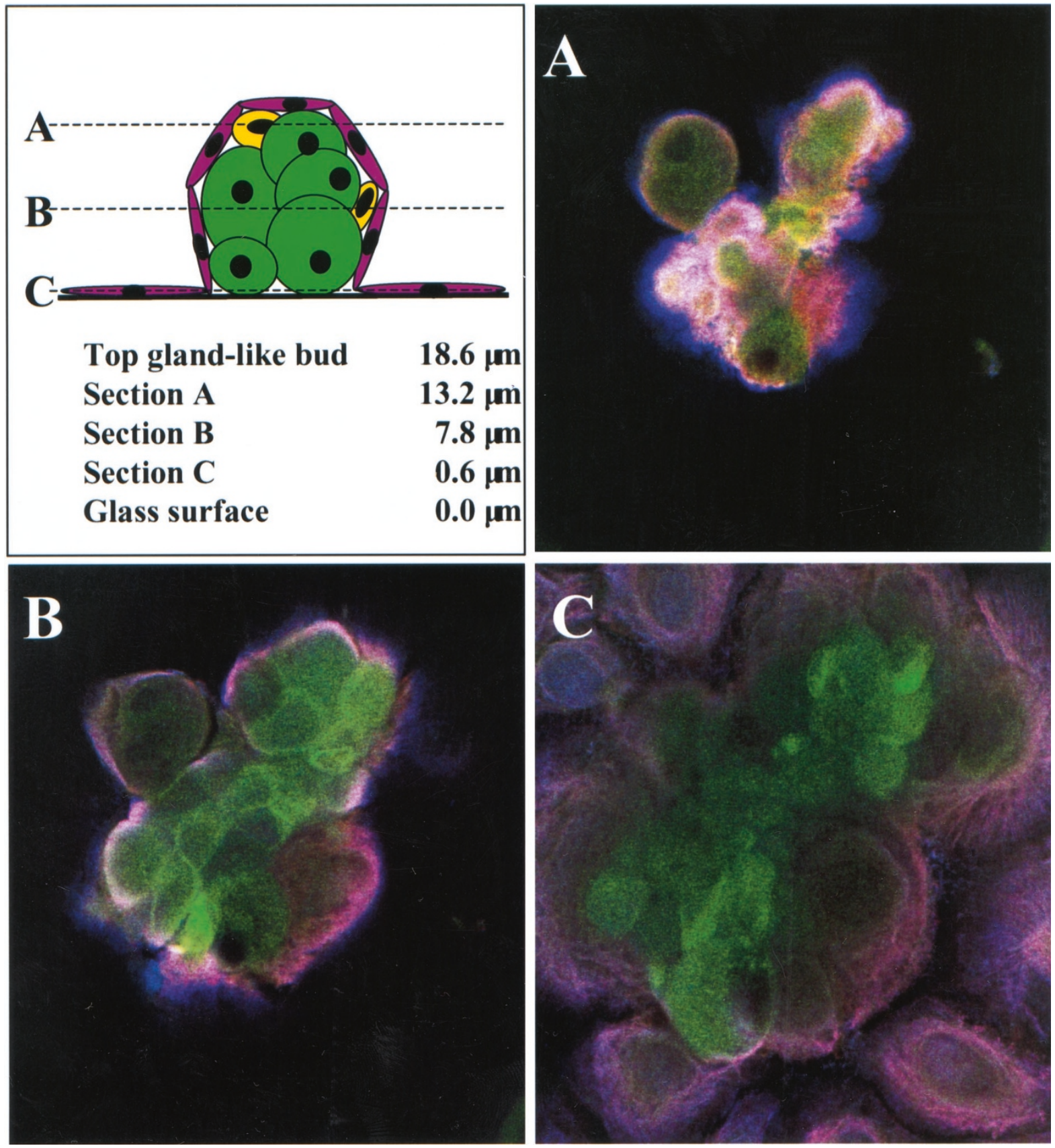

\section{Figure 4.}

Differentiation in gland-like buds after confluence of cell cultures. Gland-like buds and extensions have a complex cell composition. Cells with a basal phenotype $\left(\mathrm{K} 5^{++} / 14^{++} / 18^{+}\right.$; hybrid purple signal) cover the gland-like buds. Differentiation toward a luminal phenotype is found in the center of the gland-like buds. These cells strongly express $\mathrm{K} 18\left({\mathrm{~K} 18^{++}}^{+}\right.$; green signal). CLSM; original magnification, $\times 630$.

$\mathrm{K} 18$, but did not express K14. A second phase of differentiation manifested after confluence was characterized by the emergence of gland-like buds and extensions. Confocal scanning microscopy demonstrates that these structures are composed of an outer basal cell layer $\left(\mathrm{K}^{++} / 14^{++} / 18^{+}\right)$and a central compartment containing intermediate $\left(\mathrm{K}^{+} / 18^{+}\right)$and lumi-

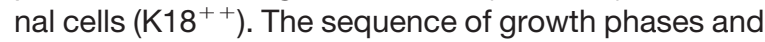
the identification of gradual keratin shifts in intermediate cells strongly indicate that basal cells are progenitors of the luminal cells in the human prostate epithe- lium. Definite evidence for the stem cell hypothesis should, however, be obtained by tracking a pure epithelial cell population and demonstrating its capability to differentiate into all other epithelial cell types in the prostate, combined with ontogenic studies of prostate epithelial development (Hayward et al, 1996; Xue et al, 1998).

The hierarchic relationship of prostate epithelium was further indicated by the focal expression of PSA in multicellular buds as a marker for exocrine differentiation. We assume that PSA expression in the mono- 
layer is localized in intermediate cells, because Bonkhoff et al found colocalization of basal cell markers and PSA expression in the normal prostate (Bonkhoff et al, 1994). Apoptosis occasionally occurred in gland-like structures, as demonstrated by caspase-3 activity. Interestingly, activated caspase-3 is usually located in the luminal cell compartment and might indicate the end-stage of differentiation in cell culture (Krajewska et al, 1997). To our surprise, we were not able to prove neuroendocrine differentiation in cell culture. Although cellular neurite-like extensions contacting neighboring cells morphologically suggested neuroendocrine differentiation, these cells did not express chromogranin A or serotonin. It is possible that other neuroendocrine granula are produced by these cells or that extra stimuli are necessary for the production of neuroendocrine granula (Bang et al, 1994; Burchardt et al, 1999; Cox et al, 1999).

In our opinion, a subgroup of basal cells that express $\mathrm{K} 5^{++} / 14^{++} / 18^{+}$corresponds to the stem cell population in the human prostate epithelium. The majority of the basal cells, however, represent early intermediate or TP/amplifying cells (De Marzo et al, 1998b; Isaacs and Coffey, 1989; Xue et al, 1998). In these cells, expression of $\mathrm{K} 14$ is gradually decreased, leading to a well-defined intermediate phenotype characterized by expression of $\mathrm{K} 5$ and 18. In some cells, up-regulation of $\mathrm{K} 18$ takes place during loss of $\mathrm{K} 14$, representing another intermediate phenotype $\left(\mathrm{K} 5^{+} / 14^{+} / 18^{++}\right)$. Loss of $\mathrm{K} 5$ seems to represent a late event in epithelial differentiation, resulting in cells strongly positive for K18. Despite the finding of epithelial cell stages with intermediate keratin expression, it is not possible to adequately mark early and late intermediate cell stages. Gradual shifts in keratin expression during differentiation imply that intermediate keratin profiles partially overlap with putative stem cells $\left(\mathrm{K} 5^{++} / 14^{++} / 18^{+}\right)$and terminally differentiated luminal cells $\left(\mathrm{K}_{1} 8^{++}\right)$, respectively. Several other proteins might be useful to mark stem, intermediate TP/amplifying, and terminally differentiated cells more adequately, because the expression pattern of multiple genes is changed during differentiation. P-cadherin, glutathione S-transferase PI, bcl-2, prostate stem cell antigen, phosphoprotein 32, and epidermal growth factor receptor are all typically present in basal cells and are down-regulated during differentiation (Cookson et al, 1997; Ibrahim et al, 1993; Jarrard et al, 1997; Kadkol et al, 1998; McDonnell et al, 1992; Reiter et al, 1998; Sherwood and Lee, 1995; Walensky et al, 1993). Luminal cells, however, up-regulate androgen receptor, PSA, and p27/kip1 (Bonkhoff and Remberger, 1993; Bonkhoff et al, 1994; De Marzo et al, 1998a). Simultaneous analysis of these specific markers and keratin profiles gives insight into the cell biology characteristics of the distinct epithelial subpopulations.

In prostate carcinoma, several basal markers are expressed, in spite of the predominance of luminal cell characteristics in this malignancy (Googe et al, 1997; Ibrahim et al, 1993; Reiter et al, 1998; Verhagen et al, 1992; Walensky et al, 1993; Yang et al, 1999). Inter- estingly, the expression of some basal cell markers is even more pronounced in androgen-independent prostate carcinoma (Gil-Diez de Medina et al, 1998; McDonnell et al, 1992). This led to the hypothesis that an intermediate cell population, the TP/amplifying cell, forms the origin of malignant transformation in the prostate epithelium (De Marzo et al, 1998a, 1998b; Verhagen et al, 1992). The present model potentiates further analysis of the cell biology characteristics of intermediate cells and the molecular regulation of epithelial differentiation. Understanding these aspects will provide important information about the cellular origin of prostate carcinoma and its androgenindependent progression.

\section{Materials and Methods}

\section{Tissue Collection and Cell Culture}

Tissue samples were obtained from 18 patients undergoing radical prostatectomy for prostate carcinoma. All of the patients gave informed consent for use of the specimens for research purposes. Immediately after surgery, fresh tissue was removed and frozen in $\mathrm{N}_{2}$. For cell culture, fresh tissue was aseptically dissected from the prostate peripheral zone using a skin biopsy punch $(5 \times 15 \mathrm{~mm})$ and transported in Dulbecco's modified Eagle's medium supplemented with $20 \%$ FCS, penicillin (100 U/ml), streptomycin (100 $\mu \mathrm{g} / \mathrm{ml})$, and amphotericin B $(2.5 \mu \mathrm{g} / \mathrm{ml})$. Three sections of the punch biopsy were removed for histopathologic analysis. Tissue samples containing malignancy were excluded from this study. The specimens were minced into 1-mm pieces, seeded in culture flasks $\left(25 \mathrm{~cm}^{2}\right)$, and covered with fresh medium. The explant cultures were maintained in a humidified incubator $\left(37^{\circ} \mathrm{C} ; 95 \% \mathrm{O}_{2}, 5 \% \mathrm{CO}_{2}\right)$. After outgrowth of the cells, culture medium was changed to keratinocyte serum-free medium (KSFM; Gibco BRL, Paisley, United Kingdom), provided with KSFM supplement (insulin, epidermal growth factor, fibroblast growth factor), BSA $(2.5 \mathrm{mg} / \mathrm{ml})$, transferrin $(2.0 \mu \mathrm{g} / \mathrm{ml})$, and minimal essential aminoacids (1\%) (Chaproniere and McKeehan, 1986). Confluent cell cultures were detached with trypsin/EDTA solution (0.05\%/0.02\%), washed, and subsequently grown in $75-\mathrm{cm}^{2}$ culture flasks. For characterization, cells (passages 2-6) were seeded on 8-well TC Chamber Slides (Gibco BRL) at a density of 2.0 to $4.0 \times 10^{4}$ cells per well in KSFM medium. The culture media were refreshed every 3 or 4 days. After 1 to 2 weeks, the cell cultures were analyzed using histochemical techniques.

\section{Direct Antibody Labeling}

The antibodies RGE53 (K18) and RCK103 (K5) were directly labeled with fluorochrome dyes using Alexa 488 and Alexa 546 protein labeling kits (Molecular Probes, Eugene, Oregon) according to the manufacturer's guide (Table 1). Briefly, $1.0 \mathrm{mg}$ of purified antibody was dissolved in $0.5 \mathrm{ml}$ PBS and provided with $50 \mu \mathrm{l}$ sodium bicarbonate $(1 \mathrm{M})$. The antibody solutions reacted for 1 hour with succinimidyl esters of Alexa 488 (RGE53) and Alexa 546 (RCK103) carboxylic 
Table 1. Keratin Antibodies and Labeling Specificities

\begin{tabular}{llcccccl}
\hline Antibody & Species & Subtype & Specificity & Labeling & Absorption & Emission & Color \\
\hline RGE53 & Mouse & IgG1 & K18 & Alexa 488 direct & $494 \mathrm{~nm}$ & $519 \mathrm{~nm}$ & Green \\
RCK103 & Mouse & IgG1 & K5 & Alexa 546 direct & $558 \mathrm{~nm}$ & $573 \mathrm{~nm}$ & Red \\
RCK107 & Mouse & IgG1 & K14 & Cy5 indirect & $649 \mathrm{~nm}$ & $670 \mathrm{~nm}$ & Blue $^{\star}$ \\
\hline
\end{tabular}

* Although Cy5-labeled K14 generates a red fluorescent signal, it is depicted as blue for distinction from the red signal of Alexa 546.

acid. Reactions were blocked by the addition of $17 \mu \mathrm{l}$ and $15 \mu \mathrm{l}$ hydroxylamine, respectively. After incubation for 30 and 15 minutes, the labeled antibody was separated from the unincorporated dye using a resin column. The antibody concentration and labeling efficiency were analyzed by spectrophotometry. The labeling efficiencies of RGE53 and RCK103 were 6.5 (optimal labeling, 4-9) and 3.6 (optimal labeling, 2-7). The labeling procedure was performed in the dark at room temperature.

\section{Triple-Staining Procedure}

Cell culture slides and $4 \mu \mathrm{m}$ cryostat sections of prostate samples were fixed in acetone for 10 minutes at $-20^{\circ} \mathrm{C}$ and air-dried for 2 hours. The slides were incubated with undiluted RCK107 antibody (K14) for 60 minutes. After washing in PBS, slides were incubated with biotinylated sheep anti-mouse $\lg (1: 100)$ for 30 minutes and conjugated with streptavidin-Cy5 (1:20) for 30 minutes. Free binding sites were blocked with $10 \%$ normal mouse serum for 30 minutes. After extensive washing, slides were incubated with directly labeled RGE53 $(20 \mu \mathrm{g} / \mathrm{ml})$ and RCK103 $(5 \mu \mathrm{g} / \mathrm{ml})$ for 1 hour (Verhagen et al, 1992). Dilutions were made in PBS / 1\% BSA. All incubations were performed in the dark at room temperature. The slides were mounted with fluorescent mounting medium (DAKO, Glostrup, Denmark) and analyzed using confocal laser scanning microscopy (Confocal System LEICA TCS NT, Leica, Wetzlar, Germany).

\section{Labeling Apoptotic Cells}

Localization of apoptotic cells was determined using an antibody to activated caspase-3 (PharMingen, San Diego, California) (Huppertz et al, 1999; Krajewska et al, 1997). Acetone-fixed, air-dried cell cultures were incubated with activated caspase- 3 antibody (1:100) at $37^{\circ} \mathrm{C}$ for 1 hour. After washing in PBS, cultures were incubated with 1:200 goat antirabbit Ig labeled with Alexa 594 (Molecular Probes) and RGE53 directly labeled with Alexa 488 for 1 hour at room temperature.

\section{Immunohistochemistry}

Exocrine and neuroendocrine differentiation was analyzed using antibodies for PSA, chromogranin A, and serotonin (DAKO). After acetone fixation and preincubation with $10 \%$ normal swine serum for 30 minutes, slides were incubated with antibodies for PSA (1:250), chromogranin $A(1: 1000)$, or serotonin (1:1000) for 1 hour at $37^{\circ} \mathrm{C}$. After washing in PBS, the cultures were reacted with swine anti-rabbit Ig labeled with alkaline phosphatase $(1: 25)$ for 1 hour at room temperature. Antibodies were visualized after incubation with alkaline phosphatase substrate (Vector Red; Vector Laboratories, Burlingame, California) for $20 \mathrm{~min}-$ utes and counterstained with hematoxylin.

\section{References}

Bang YJ, Pirnia F, Fang WG, Kang WK, Sartor O, Whitesell L, $\mathrm{Ha}$ MJ, Tsokos M, Sheahan MD, and Nguyen P (1994). Terminal neuro-endocrine differentiation of human prostate carcinoma cells in response to increased intracellular cyclic AMP. Proc Natl Acad Sci USA 91:5330-5334.

Bonkhoff H and Remberger K (1993). Widespread distribution of nuclear androgen receptors in the basal cell layer of the normal and hyperplastic human prostate. Virchows Arch A Pathol Anat Histopathol 422:35-38.

Bonkhoff H, Stein U, and Remberger K (1994). Multidirectional differentiation in the normal, hyperplastic, and neoplastic human prostate. Hum Pathol 25:42-46.

Burchardt T, Burchardt M, Chen MW, Cao Y, De la Taille A, Shabsigh A, Hayek O, Dorai T, and Buttyan R (1999). Transdifferentiation of prostate cancer cells to a neuroendocrine cell phenotype in vitro and in vivo. J Urol 162:1800-1805.

Chaproniere DM and McKeehan WL (1986). Serial culture of single adult human prostate epithelial cells in serum-free medium containing low calcium and a new growth factor from bovine brain. Cancer Res 46:819-824.

Cookson MS, Reuter VE, Linkov I, and Fair WR (1997). Glutathione S-transferase PI (GST-pi) class expression by immunohistochemistry in benign and malignant prostate tissue. J Urol 157:673-676.

Cox ME, Deeble PD, Lakhani S, and Parsons SJ (1999). Acquisition of neuroendocrine characteristics by prostate tumor cells is reversible: Implications for prostate cancer progression. Cancer Res 59:3821-3830.

Cussenot O, Berthon P, Cochand-Priollet B, Maitland NJ, and Le Duc A (1994). Immunocytochemical comparison of cultured normal epithelial prostatic cells with prostatic tissue sections. Exp Cell Res 214:83-92.

De Marzo AM, Meeker AK, Epstein JI, and Coffey DS (1998a). Prostate stem cell compartments: Expression of the cell cycle inhibitor p27Kip1 in normal, hyperplastic, and neoplastic cells. Am J Pathol 153:911-919.

De Marzo AM, Nelson WG, Meeker AK, and Coffey DS (1998b). Stem cell features of benign and malignant prostate epithelial cells. J Urol 160:2381-2392.

English HF, Santen RJ, and Isaacs JT (1987). Response of glandular versus basal rat ventral prostatic epithelial cells to androgen withdrawal and replacement. Prostate 11:229242. 
Gil-Diez de Medina S, Salomon L, Colombel M, Abbou CC, Bellot J, Thiery JP, Radvanyi F, Van der Kwast TH, and Chopin DK (1998). Modulation of cytokeratin subtype, EGF receptor, and androgen receptor expression during progression of prostate cancer. Hum Pathol 29:1005-1012.

Googe PB, McGinley KM, and Fitzgibbon JF (1997). Anticytokeratin antibody $34 \beta \mathrm{E} 12$ staining in prostate carcinoma. Am J Clin Pathol 107:219-223.

Hayward SW, Baskin LS, Haughney PC, Cunha AR, Foster BA, Dahiya R, Prins GS, and Cunha GR (1996). Epithelial development in the rat ventral prostate, anterior prostate, and seminal vesicle. Acta Anat (Basel) 155:81-93.

Huppertz B, Frank HG, and Kaufmann P (1999). The apoptosis cascade: Morphological and immunohistochemical methods for its visualization. Anat Embryol 200:1-18.

Ibrahim GK, Kerns BJ, MacDonald JA, Ibrahim SN, Kinney RB, Humphrey PA, and Robertson CN (1993). Differential immunoreactivity of epidermal growth factor receptor in benign, dysplastic, and malignant prostatic tissues. J Urol 149:170-173.

Isaacs JT and Coffey DS (1989). Etiology and disease process of benign prostatic hyperplasia. Prostate Suppl 2:33-50.

Jarrard DF, Paul R, Van Bokhoven A, Nguyen SH, Bova GS, Wheelock MJ, Johnson KR, Schalken J, Bussemakers M, and Isaacs WB (1997). P-cadherin is a basal cell-specific epithelial marker that is not expressed in prostate cancer. Clin Cancer Res 3:2121-2128.

Kadkol SS, Brody JR, Epstein JI, Kuhajda FP, and Pasternack GR (1998). Novel nuclear phosphoprotein pp 32 is highly expressed in intermediate- and high-grade prostate cancer. Prostate 34:231-237.

Krajewska M, Wang HG, Krajewski S, Zapata JM, Shabaik A, Gascoyne R, and Reed JC (1997). Immunohistochemical analysis of in vivo patterns of expression of CPP32 (Caspase3), a cell death protease. Cancer Res 57:1605-1613.

Kyprianou N and Isaacs JT (1988).: Activation of programmed cell death in the rat ventral prostate after castration. Endocrinology 122:552-562.

McDonnell TJ, Troncoso P, Brisbay SM, Logothetis C, Chung LW, Hsieh JT, Tu SM, and Campbell ML (1992). Expression of the protooncogene bcl-2 in the prostate and its association with emergence of androgen-independent prostate cancer. Cancer Res 52:6940-6944.

Moll R, Franke WW, Schiller DL, Geiger B, and Krepler R (1982). The catalog of human cytokeratins: Patterns of expression in normal epithelia, tumors, and cultured cells. Cell 31:11-24.

Nagle RB, Ahmann FR, McDaniel KM, Paquin ML, Clark VA, and Celniker $A$ (1987). Cytokeratin characterization of human prostatic carcinoma and its derived cell lines. Cancer Res 47:281-286.

Nagle RB, Brawer MK, Kittelson J, and Clark V (1991). Phenotypic relationships of prostatic intraepithelial neoplasia to invasive prostatic carcinoma. Am J Pathol 138:119-128.

Okada H, Tsubura A, Okamura A, Senzaki H, Naka Y, Komatz Y, and Morii S (1992). Keratin profiles in normal/hyperplastic prostates and prostate carcinoma. Virchows Arch A Pathol Anat Histopathol 421:157-161.
Peehl DM, Leung GK, and Wong ST (1994). Keratin expression: A measure of phenotypic modulation of human prostatic epithelial cells by growth inhibitory factors. Cell Tissue Res 277:11-18.

Reiter RE, Gu Z, Watabe T, Thomas G, Szigeti K, Davis E, Wahl M, Nisitani S, Yamashiro J, Le Beau MM, Loda M, and Witte ON (1998). Prostate stem cell antigen: A cell surface marker overexpressed in prostate cancer. Proc Natl Acad Sci USA 95:1735-1740.

Robinson EJ, Neal DE, and Collins AT (1998). Basal cells are progenitors of luminal cells in primary cultures of differentiating human prostatic epithelium. Prostate 37:149-160.

Sherwood ER, Berg LA, Mitchell NJ, McNeal JE, Kozlowski JM, and Lee C (1990). Differential cytokeratin expression in normal, hyperplastic, and malignant epithelial cells from human prostate. J Urol 143:167-171.

Sherwood ER and Lee C (1995). Epidermal growth factorrelated peptides and the epidermal growth factor receptor in normal and malignant prostate. World J Urol 13:290296.

Sherwood ER, Theyer G, Steiner G, Berg LA, Kozlowski JM, and Lee C (1991). Differential expression of specific cytokeratin polypeptides in the basal and luminal epithelia of the human prostate. Prostate 18:303-314.

Verhagen AP, Aalders TW, Ramaekers FC, Debruyne FM, and Schalken JA (1988). Differential expression of keratins in the basal and luminal compartments of rat prostatic epithelium during degeneration and regeneration. Prostate 13:2538.

Verhagen AP, Ramaekers FC, Aalders TW, Schaafsma HE, Debruyne FM, and Schalken JA (1992). Colocalization of basal and luminal cell-type cytokeratins in human prostate cancer. Cancer Res 52:6182-6187.

Walensky LD, Coffey DS, Chen TH, Wu TC, and Pasternack GR (1993). A novel M(r) 32,000 nuclear phosphoprotein is selectively expressed in cells competent for self-renewal. Cancer Res 53:4720-4726.

Xue Y, Smedts F, Debruyne FM, De la Rosette JJ, and Schalken JA (1998). Identification of intermediate cell types by keratin expression in the developing human prostate. Prostate 34:292-301.

Xue Y, Verhofstad A, Lange W, Smedts F, Debruyne F, De la Rosette JJ, and Schalken J (1997). Prostatic neuroendocrine cells have a unique keratin expression pattern and do not express $\mathrm{Bcl}-2$ : Cell kinetic features of neuroendocrine cells in the human prostate: Am J Pathol 151:17591765.

Yang XJ, Lecksell K, Gaudin P, and Epstein JI (1999). Rare expression of high-molecular-weight cytokeratin in adenocarcinoma of the prostate gland: A study of 100 cases of metastatic and locally advanced prostate cancer. Am J Surg Pathol 23:147-152.

Yang Y, Hao J, Liu X, Dalkin B, and Nagle RB (1997). Differential expression of cytokeratin mRNA and protein in normal prostate, prostatic intraepithelial neoplasia, and invasive carcinoma. Am J Pathol 150:693-704. 